\title{
Optimization of ultrasound-assisted extraction of turkish propolis and characterization of phenolic profile, antioxidant and antimicrobial activity
}

\author{
Zeynep BAKKALOGLU ${ }^{1}$ (D), Muhammet ARICI ${ }^{1 *}$, Salih KARASU ${ }^{1}$
}

\begin{abstract}
This study aimed to determine optimum conditions of the ultrasound assited extraction (UAS) parameters for different solvent types by using response surface methodology (RSM) and Box- Behnken design. The model parameters namely, time, temperature and ultrasound power significantly affected TPC value of the propolis extract $(\mathrm{P}<0.05)$. The optimum process parameters were determined as $2.95 \mathrm{~min}, 58.61{ }^{\circ} \mathrm{C}$ and $615.26 \mathrm{~W}$ for ethanol, $3 \mathrm{~min}, 60^{\circ} \mathrm{C}$ and $580 \mathrm{~W}$ for dimethyl sulfoxide (DMSO), $3 \mathrm{~min}$, $59^{\circ} \mathrm{C}$ and $591 \mathrm{~W}$ for Propylene glycol (PG) and $2.70 \mathrm{~min}, 59.19^{\circ} \mathrm{C}$ and $591.73 \mathrm{~W}$ for distilled water (DW). The extracts obtained from optimum conditions were compared with conventional solvent extraction methods (CSE). The chrysin was determined as a major phenolic compound and its value significantly differed based on the extraction and solvent types $(\mathrm{P}<0.05)$. This study suggested that the ethanolic extracts obtained from UAS could be used as natural antimicrobial and antioxidant source.
\end{abstract}

Keywords: chrysin; HPLC; FT-IR; agar diffusion.

Practical Application: Extraction optimization of propolis with differen solvents.

\section{Introduction}

Propolis is a complex bee product that honey bees (Apis mellifera) produce from the exudates of various plants, buds, wax, pollen, leaf pieces, and sprouts after subjecting some enzymatic changes. In recent years, propolis has attracted attention in the search for natural products to develop new drugs and healthy foods. Many compounds have been isolated from propolis, aromatic acids, esters, chalcones, phenolic compounds (Nna et al., 2018; Pobiega et al., 2019).

Several phenolic compounds such as chrysin, galangin, pinocembrin, pinostrobin, caffeic acid phenethyl ester, caffeic acid, and p-coumaric acid were identified in propolis (Schnitzler et al., 2010; Vargas-Sánchez et al., 2014). Propolis bioactive compounds have been linked to various health benefits such as being anti-diabetic (Kang et al., 2010), anti-inflammatory (Moura et al., 2011) and antimicrobial properties (AL-Ani et al., 2018). These bioactive and health beneficial properties are due to total phenolic compounds and their distribution. Therefore, individual phenolic compounds of the propolis should be determined to characterize the bioactive properties of propolis.

The extraction methods and solvent types are the main factors affecting phenolic compounds yield and their distribution. The conventional extraction method has been mostly used for the extraction of bioactive compounds. However, conventional extraction was considered to have some drawbacks due to a long time, high cost and degradation of product quality, while using organic solvents has to be minimized for extraction because of potential health and environmental concerns. For this reason, an alternative method should be introduced for the extraction of bioactive compounds of propolis (Pinon et al., 2019). UAE is considered an effective method in comparison with conventional methods due to its low extraction time, low solvent consumption and high yield (Fernandez-Barbero et al, 2019; Trusheva et al., 2007). Moreover, the improvement in the extraction process using ultrasound is related to the destruction of the cell walls, reduction of the particle size and enhancement of the mass transfer through the cell wall due to the collapse of bubbles produced by cavitations (Karasu et al., 2019). Solvent types are another factor affecting extraction yield and distribution of phenolic compounds, extraction temperature and time. Selecting of solvent types to increase phenolic compounds yield and decrease extraction cost (Oroian et al., 2020).

This study aimed to optimize the parameters of the UAE to obtain the maximum amount of TPC. Therefore, three independent variables namely, time (1-3 $\mathrm{min})$, temperature $\left(30-60^{\circ} \mathrm{C}\right)$ and ultrasound power (250-750 W) were applied to optimize the extraction conditions of raw propolis by using Box- Behnken design based on response surface methodology. Conventional extraction was also applied to compare its effectiveness with the optimum ultrasonic extraction (Yikmiş, 2020). For this aim, individual phenolic compounds, antioxidant activity and antimicrobial activity of the phenolic compounds were assessed.

\section{Materials and methods}

Propolis samples were collected from the Yeşilova-Denizli, Turkey. Until the extraction processes, the propolis samples were stored at $4{ }^{\circ} \mathrm{C}$ in polyethylene bags. All the standards and chemicals used in this study were obtained from Merck (Darmstadt, Germany). 


\subsection{Experimental design}

The statistical analysis was performed using the Design-Expert 7.0.0 software. RSM was used to determine the experimental design and the optimal extraction methods of propolis samples only phenolic contents of propolis. The three coded levels of extraction temperature: $-1\left(30^{\circ} \mathrm{C}\right), 0\left(45^{\circ} \mathrm{C}\right), 1\left(60^{\circ} \mathrm{C}\right)$, the extraction time: -1 (1 $\mathrm{min}), 0$ (2min), $1(3 \mathrm{~min})$ and sonication power: $-1(250 \mathrm{~W}), 0(500 \mathrm{~W}), 1(750 \mathrm{~W})$ were incorporated into the design and were analyzed in 17 combinations for each solvent (Table 1).

The quadratic model was used to determine the effect of extraction parameters on the TPC yield. Model acceptability was evaluated based on the coefficient of determination $\left(\mathrm{R}^{2}\right)$ and adj- $R^{2}$ values the lack of fit.

\subsection{Preparation and extraction of propolis samples}

Raw propolis samples were ground and homogenized. Ten grams of propolis powder extracted by $100 \mathrm{~mL}$ of ethanol-water (70:30), distilled water, dimethylsulfoxide (DMSO) and propylene glycol (PG). The ratio of solid material to the solvents were 1:10. For ultrasound extraction, samples were prepeared according to Table 1. Conventional extraction was conducted according to the method of Netíková et al. (2013) with some modifications. The solid-solvent mixtures were shaken for $24 \mathrm{~h}$ at $20^{\circ} \mathrm{C}$ using a shaking water bath. Then ultrasound-assisted (UA) and conventional (C) extracts were centrifuged at $4427 \mathrm{xg}$ for $10 \mathrm{~min}$. The extracts were then filtered through a Whatman No.1 filter paper and stored at $+4{ }^{\circ} \mathrm{C}$.

\subsection{Determination of total phenolic content}

The total phenolic content (TPC) of propolis samples was performed according to the modified method expressed by Kasote et al. (2017). $2.5 \mathrm{~mL}$ of ten fold diluted Folin Ciocalteu's phenol reagent was added to tubes containing $0.5 \mathrm{~mL}$ of propolis extracts. Then $2 \mathrm{~mL}$ of $\mathrm{Na}_{2} \mathrm{CO}_{3}(7.5 \%)$ was added to this mixture. After $30 \mathrm{~min}$ incubation, the absorbance was read at $760 \mathrm{~nm}$ with a UV/VIS spectrophotometer (Shimadzu UV-1800, Kyoto, Japan). The total phenolic content was expressed as $\mathrm{mg}$ gallic acid equivalent (GAE) per $100 \mathrm{~g}$ of raw propolis (mg GAE/100 g propolis).

\subsection{Determination of antioxidant capacity}

1,1-diphenyl-2-picrylhydrazyl (DPPH) scavenging methods were used to determine the antioxidant capacity of extracts. In the DPPH method, a $0.1 \mathrm{~mL}$ of propolis extract was mixed $4.9 \mathrm{~mL} \mathrm{DPPH}$ solution $(4.0 \mathrm{mg} / 100 \mathrm{~mL}$ methanol). The mixture was incubated for $20 \mathrm{~min}$ at room temperature, and the absorbance was read at $517 \mathrm{~nm}$ (Singh et al., 2002). The results of antioxidant capacity were expressed as $\mathrm{mg}$ Trolox equivalent per $100 \mathrm{~g}$ propolis (mg TE/100 g propolis).

\subsection{Antimicrobial activity test}

Escherichia coli 0157H7 ATCC 43888, Listeria monocytogenes ATCC 13932, Salmonella Typhimurium ATCC14028, Staphylococcus aureus ATCC 29213, Streptococcus mutans UA159 ATCC 700610, Candida albicans ATCC 10251, Penicillium carneum IBT 14042, Aspergillus flavus ATCC 15517, Aspergillus niger ATCC 9642 were used for antimicrobial activity test. These bacteria, yeast, and molds were supplied by the Department of Food Engineering, Yildiz Technical University, Istanbul-Turkey. The antimicrobial

Table 1. Experimental values of total phenolic compounds (TPC) of the different solvents extracted propolis samples obtained from Box-Behnken design.

\begin{tabular}{|c|c|c|c|c|c|c|c|}
\hline \multirow{2}{*}{ Run } & \multirow{2}{*}{ Time $[\mathrm{min}]$} & \multirow{2}{*}{ Temp. $\left[{ }^{\circ} \mathrm{C}\right]$} & \multirow{2}{*}{ Power [W] } & \multicolumn{4}{|c|}{ TPC $[\mathrm{mg} / 100 \mathrm{~g}]$} \\
\hline & & & & DW & Ethanol & DMSO & PG \\
\hline 1 & 1 & 60 & 500 & 1.88 & 97.07 & 76.07 & 22.25 \\
\hline 2 & 1 & 45 & 250 & 1.36 & 92.68 & 80.36 & 17.38 \\
\hline 3 & 1 & 30 & 500 & 1.01 & 78.26 & 78.24 & 12.71 \\
\hline 4 & 2 & 45 & 500 & 2.19 & 108.77 & 111.64 & 28.06 \\
\hline 5 & 2 & 45 & 500 & 2.15 & 108.57 & 110.87 & 28.33 \\
\hline 6 & 2 & 60 & 250 & 2.28 & 113.49 & 112.93 & 18.85 \\
\hline 7 & 2 & 60 & 750 & 3.19 & 132.84 & 110.32 & 23.52 \\
\hline 8 & 1 & 45 & 750 & 1.59 & 94.01 & 87.26 & 18.18 \\
\hline 9 & 2 & 45 & 500 & 2.28 & 106.16 & 110.11 & 27.66 \\
\hline 10 & 2 & 30 & 250 & 1.19 & 85.76 & 84.81 & 13.11 \\
\hline 11 & 2 & 45 & 500 & 2.35 & 108.03 & 101.64 & 28.46 \\
\hline 12 & 3 & 30 & 500 & 2.44 & 129.8 & 110.73 & 35.00 \\
\hline 13 & 3 & 60 & 500 & 3.30 & 140.58 & 125.60 & 35.92 \\
\hline 14 & 2 & 45 & 500 & 2.47 & 108.43 & 116.01 & 24.73 \\
\hline 15 & 2 & 30 & 750 & 2.03 & 126.59 & 104.73 & 21.24 \\
\hline 16 & 3 & 45 & 750 & 3.18 & 136.47 & 118.98 & 27.65 \\
\hline 17 & 3 & 45 & 250 & 2.87 & 101.49 & 105.87 & 22.72 \\
\hline
\end{tabular}

DW $=$ Distilled water, DMSO $=$ Dimethyl sulfoxide, $\mathrm{PG}=$ propylene glycol. 
activity of propolis samples was investigated by the agar diffusion method (Arici et al., 2005).

All test bacteria, yeast, and molds in nutrient or yeast malt extract broths were enumerated using the serial dilution method. Final cell concentrations were $10^{\wedge} 6-10^{\wedge} 7 \mathrm{cfu} / \mathrm{mL} .100 \mu \mathrm{L}$ of the bacterial suspensions were seeded on $20 \mathrm{~mL}$ of nutrient or PDA agars at $43-45^{\circ} \mathrm{C}$. The prepared bacterial cultures were poured onto petri plates and then agars were allowed to solidify. The wells at $3 \mathrm{~mm}$ diameter were cut in nutrient or PDA agars. $10 \mu \mathrm{L}$ of extracts for each propolis samples were added into the wells on nutrient or PDA agars. The solvents (ethanol, DW, DMSO, PG) were also used as control and did not show any antimicrobial activity. The plates were incubated at $35^{\circ} \mathrm{C}$ for $18-20 \mathrm{~h}$ for bacteria, and $27^{\circ} \mathrm{C}$ for $48 \mathrm{~h}$ for yeast and molds. After the incubation, the zones of growth inhibition of the propolis samples were measured by compass. All determinations were made in triplicate.

\subsection{Individual phenolic compounds using an HPLC system}

The HPLC analysis was performed on the HPLC system (LC-20AD pump, SPDM20A DAD detector, SIL-20A HT autosampler, CTO-10ASVP column oven, DGU-20A5R degasser, and CMB-20A communications bus module; (Shimadzu Corp., Kyoto, Japan). Propolis extracts were carried out on a C18 column using mobile phase $0.1 \%$ formic acid (A) and acetonitrile (B), and detection was achieved at $215 \mathrm{~nm}$. Individual phenolic compounds of conventional and ultrasound-assisted propolis extracts were determined by HPLC coupled to a diode array (HPLC-DAD, Shimadzu Corp., Kyoto, Japan). The previously obtained extracts for used in TPC analysis were filtered through a $0.45-\mu \mathrm{m}$ membrane filter and $1 \mathrm{~mL}$ of the filtered sample was analyzed in an HPLC system. Separations were conducted at $40^{\circ} \mathrm{C}$ on a reversed-phase column with a $250 \mathrm{~mm} \times 4.6 \mathrm{~mm}$ length, $5 \mu \mathrm{m}$ particle size. The mobile phases were solvent A (distilled water with $0.1 \%(\mathrm{v} / \mathrm{v})$ formic acid) and solvent $\mathrm{B}$ (acetonitrile with $0.1 \%(\mathrm{v} / \mathrm{v})$ formic acid). Gradient elution was $10 \%$ B (0-2 min), 10\%-30\% B (2-27 min), 30\%-90\% B (27-50 $\mathrm{min})$ and $90 \%-100 \% \mathrm{~B}$ (51-60 $\mathrm{min})$ and at $63 \mathrm{~min}$ returns to initial conditions. The flow rate was adjusted as $1 \mathrm{~mL} / \mathrm{min}$. Chromatograms were recorded at 254-356 nm. Identification and quantitative analysis were performed based on retention times and standard curves. The result of individual phenolics amounts was expressed as $\mathrm{mg} / \mathrm{L}$ for all samples.

\subsection{Statistical analysis}

The effect of extraction methods and solvent types on the TPC, DPPH and individual phenolic compounds were determined by ANOVA. Duncan's multiple test range was used to compare the mean values. A P-value of $<0.05$ was considered statistically significant. The statistical analyses were performed by were carried out using the Statistica software program (StatSoft, Inc., Tulsa, OK).

\section{Results and discussion}

\subsection{The effect of UAE extraction parameters on the TPC value of the propolis extracts}

Figure 1 shows the effects of ultrasound power, temperature and time on TPC for different solvent applications. It is clear from the figure that TPC values increased as the extraction time, temperature and ultrasound power increased for all solvent applications except PG. The increase in TPC yield as power increases can be explained by the cavitations effect caused by ultrasonic disrupting the material and allowing the formation of a porous structure (Vidal et al., 2020). Phenolics compounds due to cavitations are easily released from the plant matrix (Dranca \& Oroian, 2016). Similar to ultrasound power, the increase in temperature from $30^{\circ} \mathrm{C}$ to $60^{\circ} \mathrm{C}$ also increased TPC value. For the PG application, the TPC value approached its maximum value and decreased with the power value increased. This result could be explained by the degradation of phenolic compounds by increasing polyphenol oxidase activity (Zhu et al., 2019).

The positive effect of temperature can be explained by the increase in solubility of the phenolic compounds with an increase in temperature (Fachri et al., 2020). It is also seen from the figure that the solvent type affects the extraction efficiency of the phenolic compounds. The TPC value in the use of Ethanol and DMSO is higher than the use of water as a solvent. For each solvent application, the effect of different extraction parameters on the TPC value is modeled with the quadratic model. The variance analysis was performed to show the significance of extraction parameters on the TPC value. The p-value lower than 0.05 showed a significant effect of extraction parameters on TPC value.

The model parameters were shown in Table 2. In each solvent application, the model effect was significant $(\mathrm{p}<0.01)$ and lack of fit values were insignificant. In ethanol application, $\mathrm{R}^{2}$ and adj- $R^{2}$ values were determined as 0.9395 and 0.8618 , respectively. This shows that the quadratic model successfully modeled the effect of model parameters on TPC. When we examine the interaction of model parameters, only time and power interaction were found as significant. Other interactions and quadratic effects of model parameters were insignificant ( $p>0.05)$. In the DMSO application, $\mathrm{R}^{2}$ and adj- $\mathrm{R}^{2}$ values were found as 0.9238 and 0.8259 , respectively. The linear effects of model parameters are significant while their interactions are insignificant.

The quadratic effect of extraction time was significant. In PG and water applications, $\mathrm{R}^{2}$ values were found as 0.8389 and 0.9608 and adj- $\mathrm{R}^{2}$ values were found as 0.7317 and 0.9104 , respectively. In both solvent applications, the linear effect was significant, while the interactions of model parameters were found insignificant. For PG, the quadratic effect of power was significant. The models obtained for all solvent application were shown through Equations 1 to 4;

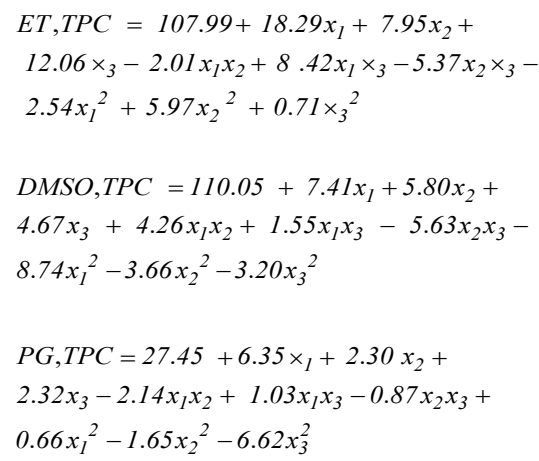


A

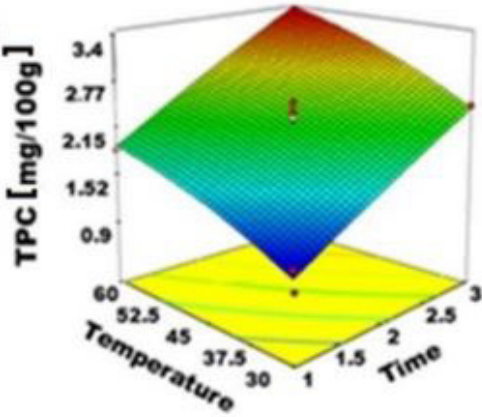

B

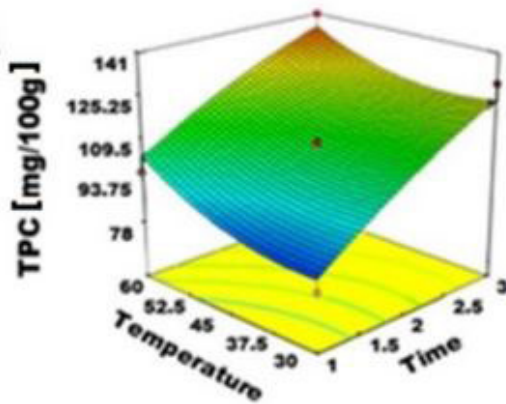

C

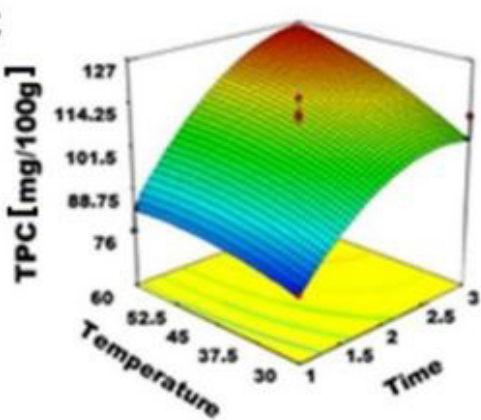

D

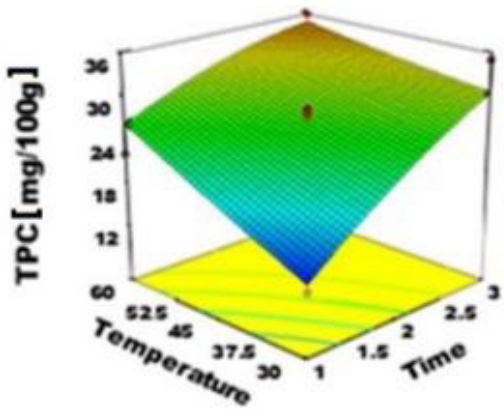

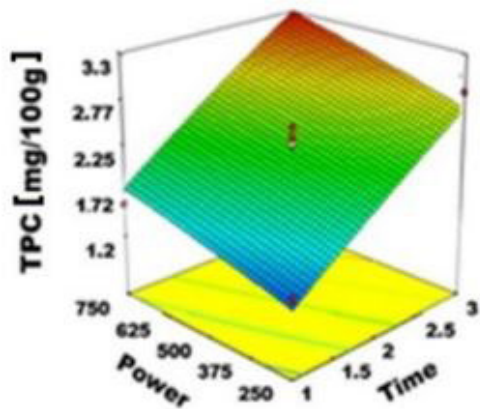
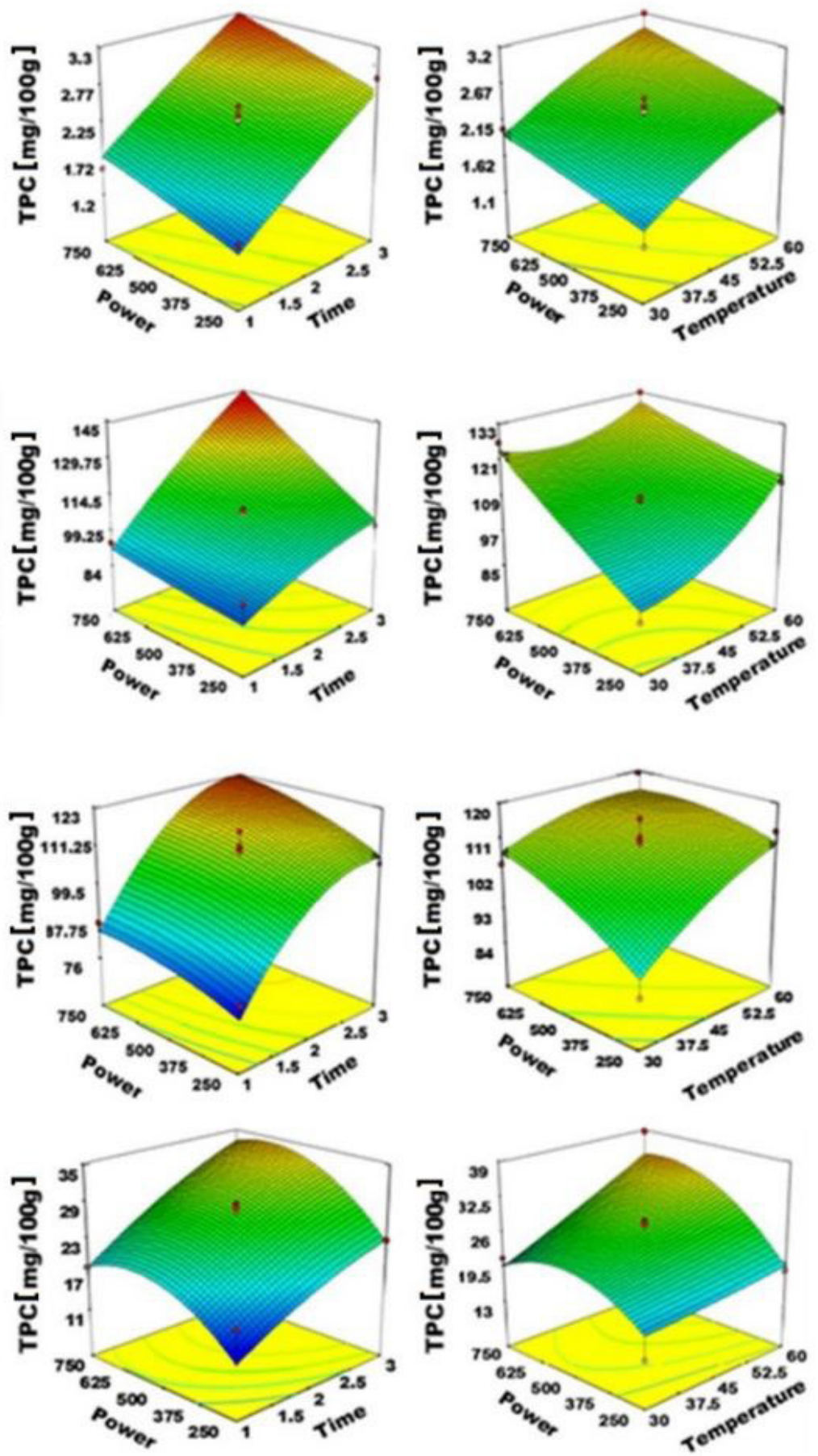

Figure 1. Response surface plot for the TPC showing the effects of A (distilled water), B (ethanol-water), C (dimethylsulfoxide) and D (propylene glycol) propolis extracts.

$D W, T P C=2.29+0.74 x_{1}+0.50 x_{2}+$

$0.29 x_{3}-0.025 x_{1} x_{2}+0.020 x_{1} x_{3}+0.018 x_{2} x_{3}-$

$0.026 x_{1}^{2}-0.10 x_{2}^{2}-0.012 x_{3}^{2}$

where, $\mathrm{x}_{1}, \mathrm{x}_{2}$, and $\mathrm{x}_{3}$ represents time, temperature and ultrasound power respectively. A positive linear, interactions and quadratic coefficients of the model parameters showed that there was a positive correlation of extraction temperature, time and ultrasound power with TPC value.

\subsection{Extraction optimization for different solvent}

Extraction optimization was performed based on the maximum TPC value for each solvent application. High desirability value was selected main criteria to determine the optimum point. The optimum process parameters were determined as $2.95 \mathrm{~min}, 58.61^{\circ} \mathrm{C}$ and $615.26 \mathrm{~W}$ for ethanol, $3 \mathrm{~min}, 60^{\circ} \mathrm{C}$ and $580 \mathrm{~W}$ for DMSO, $3 \mathrm{~min}, 59^{\circ} \mathrm{C}$ and $591 \mathrm{~W}$ for PG and $\mathrm{DW}$ $2.70 \mathrm{~min}, 59.19^{\circ} \mathrm{C}$ and $591.73 \mathrm{~W}$. The corresponding predicted 
Table 2. Quadratic model parameters for different solvent types.

\begin{tabular}{|c|c|c|c|c|c|c|c|c|c|c|c|c|c|}
\hline \multirow{2}{*}{$\begin{array}{l}\text { Regression } \\
\text { coefficients }\end{array}$} & \multirow[b]{2}{*}{$\mathrm{df}$} & \multicolumn{3}{|c|}{ Ethanol } & \multicolumn{3}{|c|}{ DMSO } & \multicolumn{3}{|c|}{ PG } & \multicolumn{3}{|c|}{ DW } \\
\hline & & $\begin{array}{l}\text { Mean } \\
\text { square }\end{array}$ & $\mathrm{F}$ & $\mathrm{p}$ & $\begin{array}{l}\text { Mean } \\
\text { square }\end{array}$ & $\mathrm{F}$ & $\mathrm{p}$ & $\begin{array}{c}\text { Mean } \\
\text { square }\end{array}$ & $\mathrm{F}$ & $\mathrm{p}$ & $\begin{array}{c}\text { Mean } \\
\text { square }\end{array}$ & $\mathrm{F}$ & $\mathrm{p}$ \\
\hline \multicolumn{14}{|l|}{ Linear } \\
\hline A & 1 & 2676.56 & 58.98 & 0.0001 & 2423.82 & 55.85 & 0.0001 & 322.83 & 15.42 & 0.0057 & 4.43 & 106.71 & $<0.0001$ \\
\hline $\mathrm{C}$ & 1 & 1163.55 & 25.64 & 0.0015 & 268.19 & 6.18 & 0.0419 & 140.53 & 6.71 & 0.0359 & 0.66 & 15.81 & 0.0054 \\
\hline \multicolumn{14}{|c|}{ Cross product } \\
\hline $\mathrm{AB}$ & 1 & 16.12 & 0.36 & 0.5699 & 72.59 & 1.67 & 0.2370 & 18.36 & 0.88 & 0.3802 & $2.500 \times 10^{-5}$ & $6.028 \times 10^{-4}$ & 0.9811 \\
\hline $\mathrm{AC}$ & 1 & 283.25 & 6.24 & 0.0411 & 9.64 & 0.22 & 0.6518 & 4.26 & 0.20 & 0.6654 & $1.600 \times 10^{-5}$ & 0.039 & 0.8499 \\
\hline \multicolumn{14}{|l|}{ Quadratic } \\
\hline B2 & 1 & 150.21 & 3.31 & 0.1117 & 26.99 & 0.62 & 0.4562 & 0.22 & 0.011 & 0.9213 & 0.046 & 1.10 & 0.3295 \\
\hline $\mathrm{C} 2$ & 1 & 2.09 & 0.046 & 0.8360 & 18.12 & 0.42 & 0.5388 & 94.86 & 4.53 & 0.0708 & $5.568 \times 10^{-4}$ & 0.013 & 0.9110 \\
\hline Lack of fit & 3 & 104.39 & 93.02 & 0.0004 & 64.78 & 2.37 & 0.2118 & 45.65 & 19.00 & 0.0079 & 0.075 & 4.56 & 0.0884 \\
\hline $\mathrm{R}^{2}$ & & 0.9395 & & & 0.9238 & & & 0.8389 & & & 0.9608 & & \\
\hline Adj-R ${ }^{2}$ & & 0.8618 & & & 0.8259 & & & 0.6317 & & & 0.9104 & & \\
\hline
\end{tabular}

$d f$ degree of freedomValues of "Prob $>$ F" less than 0.05000 indicate model terms are significant DW = Distilled water, DMSO = Dimethyl sulfooxide, $\mathrm{PG}=$ propylene glycol, $\mathrm{F}=\mathrm{F}$-value, $\mathrm{p}=\mathrm{P}$-value, $\mathrm{A}=$ extraction time, $\mathrm{B}=$ extraction temperature, $\mathrm{C}=$ ultrasound power, $\mathrm{AB}=$ extraction time and extraction temperature, $\mathrm{AC}=$ extraction time and ultrasound power, $\mathrm{BC}$ $=$ extraction temperature and ultrasound power, $\mathrm{A} 2=$ extraction time and extraction time, $\mathrm{B} 2=$ extraction temperature, $\mathrm{C} 2=\mathrm{ultrasound}$ power, $\mathrm{R}^{2}=\mathrm{R}$ squared.

TPC values were $141.66,126.24,34.20$ and $3.35 \mathrm{mg} / 100 \mathrm{~g}$ for ethanol, DMSO, PG, and DW, respectively. The predicted values were compared with the experimental value to validate the optimization process. The experimental values of the TPC at optimum points were found as 144.30, 132.58, 36.25 and $4.38 \mathrm{mg} / 100 \mathrm{~g}$ for ethanol, DMSO, PG, and DW. These results indicated that optimization was successfully validated by experimental analysis.

\subsection{The individual phenolic compounds of the propolis extracts}

In this stage, Table 3 shows the TPC, DPPH and individual phenolic components of propolis extracts obtained from the traditional extraction method and ultrasound-assisted extraction method under optimum conditions. As can be seen from Table 3, the effect of method type and different solvent applications on the amount of TPC, DPPH and individual phenolic components of extracts was found to be significant $(\mathrm{p}<0.05)$.

UAE caused a significant increase in TPC, DPPH and individual phenolic amount $(\mathrm{p}<0.05)$. Regardless of solvent and method differences, chrysin was determined as a major phenolic compound. Myricetin, quercetin and ellagic acid are other abundant phenolic components for all samples. Some phenolic compounds were detected by the UAE method while not detectable by the conventional method, which can be explained by the release of some phenolics that are bound by the capitation effect. As an example, in PG application, syringic acid, m-coumaric acid, and o-coumaric acid cannot be detected by the conventional method, while these components were determined by the UAE method. In water applications, myricetin and quercetin could be detected by the UAE method. There was a certain increase in chrysin amounts by ultrasound treatment. There was an increase of $46.7 \%$ in ethanol, 30.9\% for DMSO, 24.05 for PG, while a 9-fold increase in water application was observed. The increase in TPC value and extractability of some phenolic compounds by ultrasound application were also be reported by other studies (Gargouri et al., 2019; Trusheva et al., 2007). This indicates that optimization and ultrasound assistance is required to obtain the maximum amount of phenolic components from propolis. In similar to the extraction method, different solvent applications had also a significant effect on both the TPC and the distribution of individual phenolics $(\mathrm{p}<0.05)$. The highest value in TPC and DPPH was obtained by applying ethanol in both the CSE and the UAE. DMSO showed the highest chrysin content than other solvents applications. Syringic acid was not determined in the ethanolic application.

When we examine the literature studies, it can be seen that the individual phenolic content of propolis extracts varies according to the solvent used, method and the region where the propolis is taken (Rivero-Cruz et al., 2020). According to many studies, phenolics such as p-coumaric acid, chrysin, pinobanksin, pinostrobin, and pinocembrin are abundant 
Table 3. Phenolic compounds of ultrasound-assisted and conventional extracts of propolis (mg/100 g propolis).

\begin{tabular}{|c|c|c|c|c|c|c|c|c|}
\hline \multirow{2}{*}{ Phenolics } & \multicolumn{2}{|c|}{ Ethanol } & \multicolumn{2}{|c|}{ DMSO } & \multicolumn{2}{|c|}{ PG } & \multicolumn{2}{|c|}{ DW } \\
\hline & CSE & UAE & CSE & UAE & CSE & UAE & CSE & UAE \\
\hline Syringic acid & nd & nd & $2.61^{\mathrm{B}}$ & $3.54^{\mathrm{A}}$ & nd & 1.95 & $1.13^{\mathrm{B}}$ & $1.35^{\mathrm{A}}$ \\
\hline m-Coumaric cid & $0.21^{\mathrm{Ba}}$ & $0.48^{\mathrm{Aa}}$ & $0.22^{\mathrm{Ba}}$ & $0.50^{\mathrm{Aa}}$ & nd & $0.01 \mathrm{cc}$ & $0.05^{\mathrm{Bb}}$ & $0.18^{\mathrm{Ab}}$ \\
\hline o-Coumaric acid & $0.19^{\mathrm{Ba}}$ & $0.31^{\mathrm{Ab}}$ & $0.16^{\mathrm{Ba}}$ & $0.39^{\mathrm{Aa}}$ & nd & $0.02 \mathrm{~d}$ & $0.14^{\mathrm{B}}$ & $0.21^{\mathrm{Ac}}$ \\
\hline Caffeic acid & $4.07^{\mathrm{Ba}}$ & $5.05^{\mathrm{Aa}}$ & $4.14^{\mathrm{Ba}}$ & $5.02^{\mathrm{Aa}}$ & $3.03^{\mathrm{Bb}}$ & $3.47^{\mathrm{Ab}}$ & $1.25^{\mathrm{Bc}}$ & $1.47^{\mathrm{Ac}}$ \\
\hline p-Coumaric acid & $1.22^{\mathrm{Ba}}$ & $1.45^{\mathrm{Aa}}$ & $1.10^{\mathrm{Bb}}$ & $1.44^{\mathrm{Aa}}$ & $0.72^{\mathrm{Bc}}$ & $0.84^{\mathrm{Ab}}$ & $0.21^{\mathrm{Bd}}$ & $0.38^{\mathrm{Ac}}$ \\
\hline Ferulic acid & $0.95^{\mathrm{Ba}}$ & $1.19^{\mathrm{Aa}}$ & $0.99^{\mathrm{Aa}}$ & $1.18^{\mathrm{Aa}}$ & $0.74^{\mathrm{Bb}}$ & $0.82^{\mathrm{Ab}}$ & $0.13^{\mathrm{Bc}}$ & $0.22^{\mathrm{Ac}}$ \\
\hline Myricetin & $9.41^{\mathrm{Ba}}$ & $11.35^{\mathrm{Aa}}$ & $8.41^{\mathrm{Bb}}$ & $10.01^{\mathrm{Ab}}$ & $8.39^{\mathrm{Bc}}$ & $9.41^{\mathrm{Ac}}$ & nd & $0.84 \mathrm{~d}$ \\
\hline AA [mg Trolox/g] & $4.96^{\mathrm{Ba}}$ & $835.34^{\mathrm{Aa}}$ & $4.85^{\mathrm{Ab}}$ & $818.74^{\mathrm{Bb}}$ & $4.83^{\mathrm{Bb}}$ & $735.01^{\mathrm{Ac}}$ & $0.48^{\mathrm{Bc}}$ & $382.68^{\mathrm{Ad}}$ \\
\hline
\end{tabular}

Different capital letters in the same line indicate the significance of the extraction method on individual phenolic $(\mathrm{p}<0.05)$. Different lower case letters on the same line indicate the significance of the solvent type on individual phenolic $(\mathrm{p}<0.05) ; \mathrm{CSE}=$ Conventional solvent extraction, UAE $=\mathrm{Ultrasound}$ assisted extraction, $\mathrm{DW}=\mathrm{Distilled}$ water, $\mathrm{DMSO}=\mathrm{Dimethyl}$ sulfoxide, $\mathrm{PG}=$ propylene glycol, $\mathrm{nd}=$ not detected, $\mathrm{TPC}=$ Total Phenolic Content, $\mathrm{AA}=$ Antioxidant Activity.

phenolics in propolis extracts (Mani \& Natesan, 2018; Ozdal et al., 2019; Popova et al., 2017; Wozniak et. al, 2019). In a similar to our studies, chrysin was found one of the major phenolic compounds by ultrasound-assisted extraction (Yuan et al., 2019). In their study, pinocembrin, chrysin, and pinobanksin were found as $30.96,30.56$ and $29.97 \mathrm{mg} / \mathrm{g}$ respectively. Pavlovic et al. (2020) reported that chrysin was found as major phenolics with the amount of $33.62-35.64 \mathrm{mg} / \mathrm{g}$. AL-Ani et al. (2018) studied the characterization of antimicrobial activities of European propolis. It was reported that chrysin was found abundant phenolics obtained from Czech and Irish propolis. Chrysin is a dihydroxyflavone and shows many biological activities such as antioxidant, anti-inflammatory, anticancer, and antiviral activities (Mani \& Natesan, 2018). Our study showed that ethanolic and DMSO extract of the propolis was rich in chrysin.

Figure 2 showed FTIR spectrum of propolis extracts obtained from different solvent. In addition to phenolic components, different components could be dissolved in these solvents. Therefore, it is necessary to examine the specific bands to differentiate phenolic compounds. Especially $\mathrm{C}-\mathrm{OH}, \mathrm{C}=\mathrm{O}, \mathrm{C}=\mathrm{C}$ and $\mathrm{CH}$ vibrations can provide very useful information in the evaluation of the FTIR spectrum for phenolic compounds.

We can examine these stretching vibrations especially between 1040-1637 $\mathrm{cm}^{-1}$. The band around $1040 \mathrm{~cm}^{-1}$ might be due to $\mathrm{C}-\mathrm{O}$ valence vibrations and the band at $1375 \mathrm{~cm}^{-1}$ is related to $\mathrm{C}-\mathrm{OH}$ deformation vibration of the phenol ring. The band between 1437 and $1443 \mathrm{~cm}^{-1}$ might be related to the $\mathrm{C}=\mathrm{O}$ and $\mathrm{CH}$ vibrations in the aromatic ring. The band between 1634-1637 is related to stretching vibrations between $\mathrm{C}=0, \mathrm{C}=\mathrm{C}$. This band is very important in distinguishing flavonoids. This band was observed in all solvents. The band observed in region of 4000-2000, whic involves aliphatic C-H and $\mathrm{OH}$ absorbtion, gives limited data about polyphenolic compounds. Thefore, FTIR could be used in identification of phenolic compounds extracted from propolis.

\subsection{Antimicrobial effects of propolis extracts}

In the study, the antibacterial and antifungal activities of different solvent extracts were determined by evaluating the inhibition zones using five bacterial strains, three mold strains, and one yeast strain. According to the results in Table 4, all different extracts of propolis showed antibacterial and antifungal activity. The effect of extraction methods and solvent type significantly affected antimicrobial activity $(\mathrm{p}<0.05)$. UAE significantly increased inhibition zone diameter compared to CSE for all samples. Among the same methods, ethanolic extracts showed higher antimicrobial activity than others $(\mathrm{p}<0.05)$. The ethanol and DMSO extracts of propolis exhibited the higher antimicrobial activity than the those of PG ad DW. However, DW extracts of propolis showed a very weak inhibitory action against all test microorganisms. Antibacterial activity of propolis is reported to be due to its components such as phenolics, flavonoids, aromatic acids and esters (Pobiega et al., 2019). The high levels of phenolic compounds might cause the denaturation of enzymes and bacterial cell death (Takaisi-kikuni \& Schilcher, 1994). Generally, the antifungal activity of propolis extracts is stronger than antibacterial activity. Therefore, the UAE extract of propolis showed a higher inhibitory effect on the growth of the test microorganisms compared to the CSE extract of propolis. Pobiega et al. (2019) reported that the increase in the time of the ultrasonication process showed a stronger inhibitory effect against test microorganisms (Carrillo-Lopez et al., 2019). The propolis 


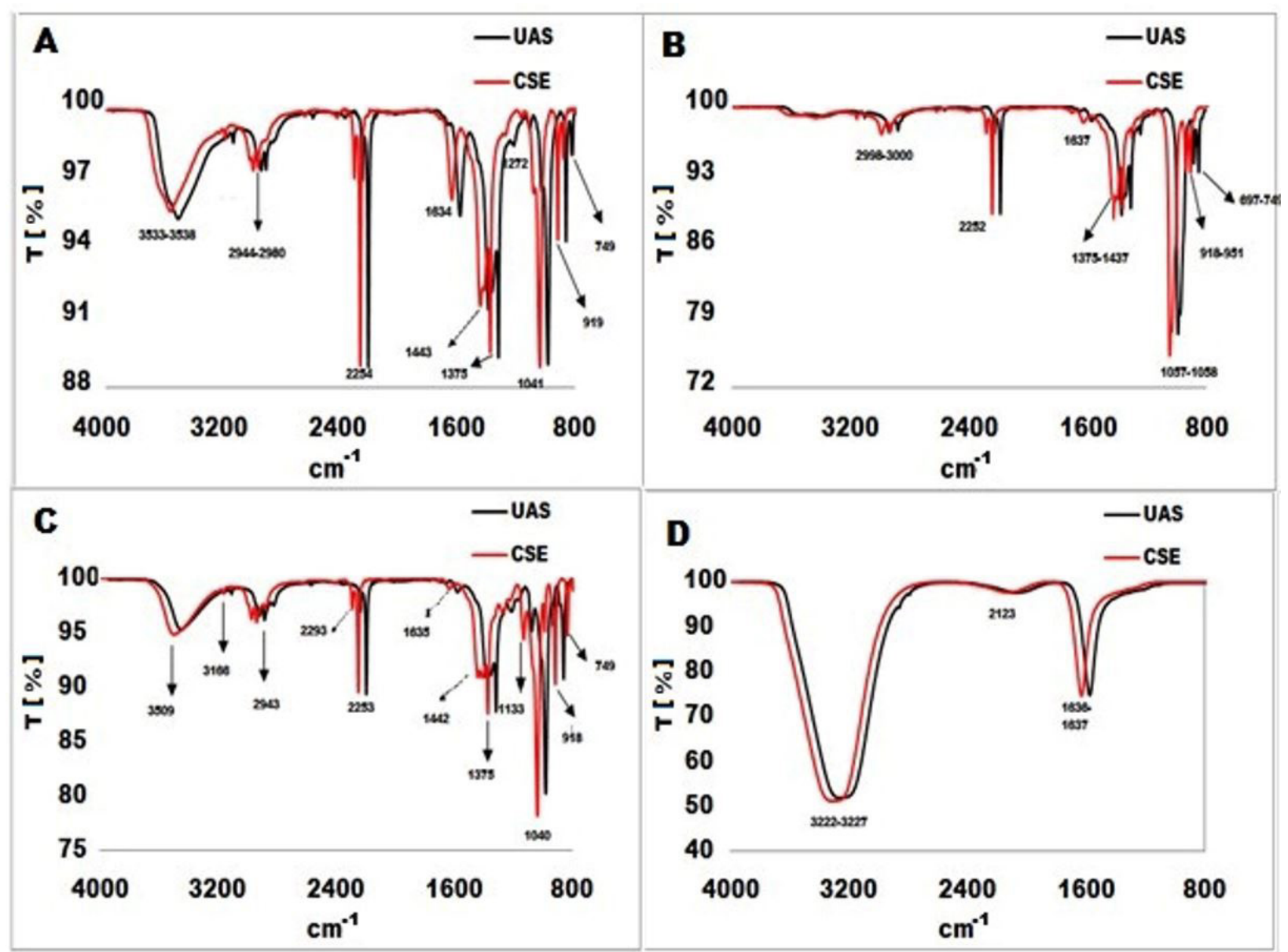

Figure 2. FTIR spectrums of propolis extracts ((A) Ethanol, (B) DMSO, (C) PG and (D) DW)).

Table 4. Antimicrobial activity of the propolis extracts.

\begin{tabular}{|c|c|c|c|c|c|c|c|c|}
\hline \multirow{3}{*}{ Microorganisms } & \multicolumn{8}{|c|}{ Average halo (mm) } \\
\hline & \multicolumn{2}{|c|}{ Ethanol } & \multicolumn{2}{|c|}{ DMSO } & \multicolumn{2}{|c|}{ PG } & \multicolumn{2}{|c|}{ DW } \\
\hline & CSE & UAE & CSE & UAE & CSE & UAE & CSE & UAE \\
\hline Escherichia coli $0157 H 7$ ATCC 43888 & $7.60^{\mathrm{Ba}}$ & $9.20^{\mathrm{Aa}}$ & $7.20^{\mathrm{Bb}}$ & $8.00^{\mathrm{Ab}}$ & $6.40^{\mathrm{Bc}}$ & $8.20^{\mathrm{Ab}}$ & $5.00^{\mathrm{Bd}}$ & $6.20^{\mathrm{Ac}}$ \\
\hline Listeria monocytogenes ATCC 13932 & $10.25^{\mathrm{Ba}}$ & $12.50^{\mathrm{Aa}}$ & $10.20^{\mathrm{Ba}}$ & $12.40^{\mathrm{Aa}}$ & $9.60^{\mathrm{Bb}}$ & $11.00^{\mathrm{Ab}}$ & $6.00^{\mathrm{Bc}}$ & $7.00^{\mathrm{Ac}}$ \\
\hline Salmonella Typhimurium ATCC 14028 & $7.25^{\mathrm{Ba}}$ & $8.30^{\mathrm{Aa}}$ & $7.50^{\mathrm{Ba}}$ & $8.20^{\text {Aa }}$ & $6.20^{\mathrm{Bb}}$ & $7.40^{\mathrm{Ab}}$ & $4.20^{\mathrm{Bc}}$ & $5.00^{\mathrm{Ac}}$ \\
\hline Staphylococcus aureus ATCC 29213 & $8.50^{\mathrm{Ba}}$ & $10.00^{\mathrm{Aa}}$ & $8.80^{\mathrm{Ba}}$ & $10.00^{\mathrm{Aa}}$ & $7.00^{\mathrm{Bb}}$ & $8.50^{\mathrm{Ab}}$ & $6.40^{\mathrm{Bc}}$ & $7.50^{\mathrm{Ac}}$ \\
\hline Streptococcus mutans UA159 (ATCC 700610) & $10.20^{\mathrm{Ba}}$ & $11.50^{\mathrm{Aa}}$ & $9.20^{\mathrm{Bb}}$ & $10.80^{\mathrm{Ab}}$ & $8.20^{\mathrm{Bc}}$ & $9.40^{\mathrm{Ac}}$ & $7.10^{\mathrm{Bd}}$ & $7.80^{\mathrm{Aa}}$ \\
\hline Candida albicans 10251 & $9.30^{\mathrm{Ba}}$ & $11.20^{\mathrm{Aa}}$ & $9.20^{\mathrm{Ba}}$ & $10.40^{\mathrm{Ab}}$ & $9.00^{\mathrm{Bb}}$ & $10.40^{\mathrm{Ab}}$ & $4.40^{\mathrm{Bc}}$ & $4.90^{\mathrm{Ac}}$ \\
\hline Penicillium carneum IBT14 042 & $19.50^{\mathrm{Ba}}$ & $21.50^{\mathrm{Aa}}$ & $14.40^{\mathrm{Bb}}$ & $16.80^{\mathrm{Ab}}$ & $13.20^{\mathrm{Bc}}$ & $15.80^{\mathrm{Ab}}$ & $6.20^{\mathrm{Bd}}$ & $7.20^{\mathrm{Ac}}$ \\
\hline Aspergillus flavus ATCC 15517 & $12.20^{\mathrm{Ba}}$ & $15.20^{\mathrm{Aa}}$ & $11.50^{\mathrm{Bb}}$ & $12.70^{\mathrm{Ab}}$ & $11.00^{\mathrm{Bc}}$ & $12.30^{\mathrm{Ac}}$ & $6.00^{\mathrm{Bd}}$ & $8.50^{\mathrm{Ad}}$ \\
\hline Aspergillus niger АТCС 9642 & $11.50^{\mathrm{Ba}}$ & $12.50^{\mathrm{Aa}}$ & $11.20^{\mathrm{Ba}}$ & $11.50^{\mathrm{Ab}}$ & $10.00^{\mathrm{Bb}}$ & $10.80^{\mathrm{Ac}}$ & $7.50^{\mathrm{Bc}}$ & $7.20^{\mathrm{Ad}}$ \\
\hline
\end{tabular}

Mean values of the diameters of inhibition zones in $\mathrm{mm}$. Different capital letters in the same line indicate the significance of the extraction method on individual phenolic ( $\mathrm{p}<0.05$ ). Different lower case letters on the same line indicate the significance of the solvent type on individual phenolic $(\mathrm{p}<0.05)$. CSE $=\mathrm{Conventional} \mathrm{solvent} \mathrm{extraction,} \mathrm{UAE}=\mathrm{Ultrasound}$ assisted extraction, DW = Distilled water, DMSO = Dimethyl sulfoxide, $\mathrm{PG}=$ propylene glycol.

extracts showed a stronger antibacterial effect on gram-positive bacterias than gram-negative bacterias (Chen et al., 2018).

\section{Conclusion}

In this study, the parameters of the ultrasound-assisted extraction method have been optimized. Extraction time, temperature, and ultrasound power significantly affected the TPC value. As the temperature (30-60), duration (1-3 min) and ultrasound power (250-750 W) increased, the phenolic substance extraction efficiency also increased. The type of solvent used and the ultrasonic application had a significant effect on both the TPC value and the distribution of phenolic compounds. The application of ultrasound also increased the antimicrobial 
effect significantly. The results of this study showed that with UAS optimization both the extraction time was shortened and the phenolic and antimicrobial effect was increased.

\section{Acknowledgements}

This research supported by Yildiz Technical University Coordinator of Scientific Research Projects, Project Number: 3467.

\section{References}

AL-Ani, I., Zimmermann, S., Reichling, J., \& Wink, M. (2018). Antimicrobial activities of european propolis collected from various geographic origins alone and in combination with antibiotics. Medicines (Basel, Switzerland), 5(1), 2. http://dx.doi.org/10.3390/ medicines5010002. PMid:29301368.

Arici, M., Sagdic, O., \& Gecgel, U. (2005). Antibacterial effect of Turkish black cumin (Nigella sativa L.) oils. Grasas y Aceites, 56(4). http:// dx.doi.org/10.3989/gya.2005.v56.i4.90.

Carrillo-Lopez, L. M., Luna-Rodriguez, L., Alarcon-Rojo, A. D., \& HuertaJimenez, M. (2019). High intensity ultrasound homogenizes and improves quality of beef longissimus dorsi. Food Science and Technology (Campinas), 39(Suppl 1), 332-340. http://dx.doi.org/10.1590/fst.05218.

Chen, Y. W., Ye, S. R., Ting, C., \& Yu, Y. H. (2018). Antibacterial activity of propolins from Taiwanese green propolis. Journal of Food and Drug Analysis, 26(2), 761-768. http://dx.doi.org/10.1016/j. jfda.2017.10.002. PMid:29567247.

Dranca, F., \& Oroian, M. (2016). Optimization of ultrasound-assisted extraction of total monomeric anthocyanin (TMA) and total phenolic content (TPC) from eggplant (Solanum melongena L.) peel. Ultrasonics Sonochemistry, 31, 637-646. http://dx.doi.org/10.1016/j. ultsonch.2015.11.008. PMid:26701808.

Fachri, B. A., Sari, P., Yuwanti, S., \& Subroto, E. (2020). Experimental study and modeling on supercritical CO2 extraction of Indonesian raw propolis usiing response surface method: influence of pressure, temperature and $\mathrm{CO} 2$ mass flowrate on extraction yield. Chemical Engineering Research \& Design, 153, 452-462. http://dx.doi. org/10.1016/j.cherd.2019.11.014.

Fernandez-Barbero, G., Pinedo, C., Espada-Bellido, E., FerreiroGonzález, M., Carrera, C., Palma, M., \& Garcia-Barroso, C. (2019). Optimization of ultrasound-assisted extraction of bioactive compounds from jabuticaba (Myrciaria cauliflora) fruit through a Box-Behnken experimental design. Food Science and Technology (Campinas), 39(4), 1018-1029. http://dx.doi.org/10.1590/fst.16918.

Gargouri, W., Osés, S. M., Fernández-Muiño, M. A., Sancho, M. T., \& Kechaou, N. (2019). Evaluation of bioactive compounds and biological activities of Tunisian propolis. LWT, 111, 328-336. http:// dx.doi.org/10.1016/j.lwt.2019.05.044.

Kang, L. J., Lee, H. B., Bae, H. J., \& Lee, S. G. (2010). Antidiabetic effect of propolis: reduction of expression of glucose-6-phosphatase through inhibition of Y279 and Y216 autophosphorylation of GSK-3 $\alpha / \beta$ in HepG2 cells. Phytotherapy research: PTR, 24(10), 1554-1561. http:// dx.doi.org/10.1002/ptr.3147. PMid:20878710.

Karasu, S., Bayram, Y., Ozkan, K., \& Sagdic, O. (2019). Extraction optimization crocin pigments of saffron (Crocus sativus) using response surface methodology and determination stability of crocin microcapsules. Journal of Food Measurement and Characterization, 13(2), 15151523. http://dx.doi.org/10.1007/s11694-019-00067-x.

Kasote, D.M., Pawar, M., Bhatia, R., Nandre, V., Gundu, S., Jagtap, S., \& Kulkarni, M. (2017). HPLC, NMR based chemical profiling and biological characterisation of Indian propolis. Fitoterapia,
122, 52-60. http://dx.doi.org/10.1016/j.fitote.2017.08.011. PMid:28842358.

Mani, R., \& Natesan, V. (2018). Chrysin: sources, beneficial pharmacological activities, and molecular mechanism of action. Phytochemistry, 145, 187-196. http://dx.doi.org/10.1016/j.phytochem.2017.09.016. PMid:29161583.

Moura, S. A., Negri, G., Salatino, A., Lima, L. D., Dourado, L. P., Mendes, J. B., Andrade, S. P., Ferreira, M. A., \& Cara, D. C. (2011). Aqueous extract of brazilian green propolis: primary components, evaluation of inflammation and wound healing by using subcutaneous implanted sponges. Evidence-based complementary and alternative medicine : eCAM, 2011, 748283. http://dx.doi.org/10.1093/ecam/ nep112. PMid:19690045.

Netíková, L., Bogusch, P., \& Heneberg, P. (2013). Czech ethanolfree propolis extract displays inhibitory activity against a broad spectrum of bacterial and fungal pathogens. Journal of Food Science, 78(9), M1421-M1429. http://dx.doi.org/10.1111/1750-3841.12230. PMid:23915150.

Nna, V. U., Bakar, A. B. A., \& Mohamed, M. (2018). Malaysian propolis, metformin and their combination, exert hepatoprotective effect in streptozotocin-induced diabetic rats. Life Sciences, 211, 40-50. http:// dx.doi.org/10.1016/j.lfs.2018.09.018. PMid:30205096.

Oroian, M., Dranca, F., \& Ursachi, F. (2020). Comparative evaluation of maceration, microwave and ultrasonic-assisted extraction of phenolic compounds from propolis. Journal of Food Science and Technology, 57(1), 70-78. http://dx.doi.org/10.1007/s13197-01904031-x. PMid:31975709.

Ozdal, T., Ceylan, F. D., Eroglu, N., Kaplan, M., Olgun, E. O., \& Capanoglu, E. (2019). Investigation of antioxidant capacity, bioaccessibility and LC-MS/MS phenolic profile of Turkish propolis. Food Research International, 122, 528-536. http://dx.doi.org/10.1016/j. foodres.2019.05.028. PMid:31229108.

Pavlovic, R., Borgonovo, G., Leoni, V., Giupponi, L., Ceciliani, G., Sala, S., Bassoli, A., \& Giorgi, A. (2020). Effectiveness of different analytical methods for the characterization of propolis: a case of study in Northern Italy. Molecules (Basel, Switzerland), 25(3), 504. http://dx.doi.org/10.3390/molecules25030504. PMid:31979422.

Pinon, M., Alarcon-Rojo, A., Paniwnyk, L., Mason, T., Luna, L., \& Renteria, A. (2019). Ultrasound for improving the preservation of chicken meat. Food Science and Technology (Campinas), 39(Suppl 1), 129135. http://dx.doi.org/10.1590/fst.39017.

Pobiega, K., Kraśniewska, K., Derewiaka, D., \& Gniewosz, M. (2019). Comparison of the antimicrobial activity of propolis extracts obtained by means of various extraction methods. Journal of Food Science and Technology, 56(12), 5386-5395. http://dx.doi.org/10.1007/s13197019-04009-9. PMid:31749486.

Popova, M., Giannopoulou, E., Skalicka-Woźniak, K., Graikou, K., Widelski, J., Bankova, V., Kalofonos, H., Sivolapenko, G., GawełBęben, K., Antosiewicz, B., \& Chinou, I. (2017). Characterization and biological evaluation of propolis from Poland. Molecules (Basel, Switzerland), 22(7), 1159. http://dx.doi.org/10.3390/molecules22071159. PMid:28696397.

Rivero-Cruz, J.F., Granados-Pineda, J., Pedraza-Chaverri, J., Pérez-Rojas, M. J., Kumar-Passari, A., Diaz-Ruiz, G., \& Rivero-Cruz, E. B. (2020). Phytochemical constituents, antioxidant, cytotoxic, and antimicrobial activities of the ethanolic extract of Mexican Brown Propolis. Antioxidants, 9(1), 70. http://dx.doi.org/10.3390/antiox9010070. PMid:31940981.

Schnitzler, P., Neuner, A., Nolkemper, S., Zundel, C., Nowack, H., Sensch, K., \& Reichling, J. (2010). Antiviral activity and mode of 
action of propolis extracts and selected compounds. Phytotherapy Research, 24(Suppl 1), S20-S28. https://doi.org/10.1002/ptr.2868.

Singh, R. P., Chidambara Murthy, K. N., \& Jayaprakasha, G. K. (2002). Studies on the antioxidant activity of pomegranate (Punica granatum) peel and seed extracts using in vitro models. Journal of Agricultural and Food Chemistry, 50(1), 81-86. http://dx.doi.org/10.1021/jf010865b. PMid:11754547.

Takaisi-kikuni, N. B., \& Schilcher, H. (1994). Electron-microscopic and microcalorimetric investigations of the possible mechanism of the antibacterial action of a defined propolis provenance. Planta Medica, 60(3), 222-227. http://dx.doi.org/10.1055/s-2006-959463. PMid:8073087.

Trusheva, B., Trunkova, D., \& Bankova, V. (2007). Different extraction methods of biologically active components from propolis: a preliminary study. Chemistry Central Journal, 1(1), 13. http://dx.doi. org/10.1186/1752-153X-1-13. PMid:17880743.

Vargas-Sánchez, R. D., Torrescano-Urrutia, G. R., Acedo-Félix, E., Carvajal-Millán, E., González-Córdova, A. F., Vallejo-Galland, B., Torres-Llanez, M. J., \& Sánchez-Escalante, A. (2014). Antioxidant and antimicrobial activity of commercial propolis extract in beef patties. Journal of Food Science, 79(8), C1499-C1504. http://dx.doi. org/10.1111/1750-3841.12533. PMid:25039743.

Vidal, A. R., Cansian, R. L., Mello, R. D. O., Kubota, E. H., Demiate, I. M., Zielinski, A. A. F., \& Dornelles, R. C. P. (2020). Effect of ultrasound on the functional and structural properties of hydrolysates of different bovine collagens. Food Science and Technology (Campinas), 40(2), 346-353. http://dx.doi.org/10.1590/fst.00319.

Wozniak, M., Mrowczynska, L., Waskiewicz, A., Rogozinski, T., \& Ratajczak, I. (2019). Phenolic profile and antioxidant activity of propolis extracts from Poland. Natural Product Communications, 14(5), 1934578X1984977. http://dx.doi. org/10.1177/1934578X19849777.

Yikmiş, S. (2020). Effect of ultrasound on different quality parameters of functional sirkencubin syrup. Food Science and Technology (Campinas), 40(1), 258-265. http://dx.doi. $\operatorname{org} / 10.1590 /$ fst. 40218 .

Yuan, Y., Zheng, S., Zeng, L., Deng, Z., Zhang, B., \& Li, H. (2019). The phenolic compounds, metabolites, and antioxidant activity of propolis extracted by ultrasound-assisted method. Journal of Food Science, 84(12), 3850-3865. http://dx.doi.org/10.1111/17503841.14934. PMid:31750945.

Zhu, L., Zhu, L., Murtaza, A., Liu, Y., Liu, S., Li, J., Iqbal, A., Xu, X., Pan, S., \& Hu, W. (2019). Ultrasonic processing induced activity and structural changes of polyphenol oxidase in orange (Citrus sinensis Osbeck). Molecules (Basel, Switzerland), 24(10), 1922. http://dx.doi.org/10.3390/molecules24101922. PMid:31109085. 